\title{
Relative excitation of the seismic shear waves $S n$ and $L g$ as a function of source depth and their propagation from Melanesia and Banda arcs to Australia
}

\author{
Barazangi M. $\left({ }^{*}\right)$ - Oliver J. $\left({ }^{*}\right)$ - Isacks B. $\left({ }^{*}\right)$
}

Received on October 7 th, 1977

\begin{abstract}
Riassunto. - L'attività sismica associata alla collisione della parte continentale della placca Australiana con gli archi oceanici della Melanesia lungo la Papua New Guinea e con l'arco di Banda, fornisce un'insolita opportunità per studiare l'eccitazione relativa delle onde sismiche di taglio $S n$ e $L g$. Tali onde sono prodotte da terremoti localizzati lungo gli archi negli ultimi $200 \mathrm{~km}$ della Terra e registrate dalle stazioni australiane WWSSN a Charters Towers $(C T A)$ e ad Alice Springs $(A S P)$. I tragitti per queste stazioni sono prevalentemente continentali. I dati mostrano chiaramente che, per eventi localizzati a profondità crostali, la $L g$ è la fase predominante nelle registrazioni, mentre la $S n$ è assente o molto debole. Per eventi più profondi di circa $50-70 \mathrm{~km}$, la $S n$ diventa nelle registrazioni la fase dominante. Queste osservazioni sono in un accordo qualitativo con la definizione delle onde $S n$ ed $L g$, che sono i più importanti aspetti di onde superficiali, e le ampiezze dello spostamento della particella sono massime entro la crosta per le $L g$ e massime entro lo strato del mantello litosferico per le $S n$. I dati suggeriscono o che l'onda guida crostale per le $L g$ è più efficiente di quella per le $S n$, o che la $L g$ è più facilmente eccitabile della $S n$. Non si osserva nessuna chiara onda $L g$ per terremoti superficiali quando la lunghezza del segmento del tragitto che attraversa la struttura oceanica è superiore a circa $200 \mathrm{~km}$. Inoltre, il vulcanismo Quaternario diffuso entro l'area "stabile» di Papua New Guinea a sud della cintura mobile non sembra disturbare l'efficace trasmissione dell'energia di taglio di alta frequenza $(1 \mathrm{~Hz})$. I tragitti relativi ad eventi localizzati lungo gli archi delle Nuove Ebridi, di Salomone e della Nuova Britannia fino all'Australia, attraversano strutture oceaniche: da questi tragitti non si osserva nessuna onda $\mathrm{Lg}$. La incapacità delle onde $\mathrm{Sn}$ di propagarsi lungo questi tragitti per eventi superficiali ed intermedi, può essere così spiegata: 1) Per le Nuove Ebridi l'incapacità delle onde $S n$ di propagarsi per quei tragitti che
\end{abstract}

(*) Department of Geological Sciences, Cornell University, Ithaca, New York 14853. 
superano i $20^{\circ}$ di distanza è legata all'età relativamente giovane (dal più basso al medio Eocene) della litosfera suboceanica del Mar di Corallo. Come proposto da CiInn, Isacks e Baranzagı (1978), detta litosfera relativamente sottile non è probabilmente un'onda guida efficiente per energia di taglio di $1 \mathrm{~Hz}$ ca.. 2) L'incapacità delle onde $S_{n}$ relative ad eventi localizzati lungo gli archi della parte settentrionale di Salomone e della Nuova Britannia di propagarsi, è probabilmente dovuta ad attenuazione anormale nel mantello superiore al di sotto del bacino di Woodlark e della Papua New Guinea sud-orientale. 3) L'incapacità delle onde $S n$ relative ad eventi più profondi di $150 \mathrm{~km}$ localizzati nella parte più occidentale della zona di immersione settentrionale di Benioff dell'arco della Nuova Britannia potrebbe essere dovuto $o$ all'isolamento strutturale del segmento discendente quasi verticale della placca in cui gli eventi avvengono, oppure alla complessità strutturale delle placche nclla regione che interrompe l'onda guida delle onde Sn nelle stazioni Australiane. Questa caratteristica strutturale potrebbe essere il risultato della collisione della placca Australiana con l'arco della Nuova Britannia.

SUMmary. - Seismic activity associated with the collision of the continental part of the Australian plate with the oceanic Melanesian arcs along Papua New Guinea and the Banda arc provides an unusual opportunity to study the relative excitation of the seismic shear waves $S n$ and $L g$. These waves are produced by earthquakes located along the arcs in the upper $200 \mathrm{~km}$ of the earth and are recorded by the Australian WWSSN Stations at Charters Towers (CTA) and Alice Springs $(A S P)$. The paths to these stations are predominantly continental. The data clearly show that for events located at crustal depths, $L g$ is the predominant phase on the records and $S n$ is either absent or very weak. For events deeper than about $50-70 \mathrm{~km}, S n$ becomes the predominant phase on the records. These observations are in qualitative agreement with the explanations of $S n$ and $L g$ as higher modes of surface waves, for the particle displacement amplitudes are maximum within the crust for $L g$ and maximum within the lid of the lithospheric mantle for $S n$. The data suggest that either the crustal wave guide for $L g$ is more efficient than that for $S n$, or that $L g$ is more easily excited than $S_{n}$. No clear $\mathrm{Lg}$ is observed from shallow earthquakes when the length of the segment of the path crossing oceanic structure is greater than about $200 \mathrm{~km}$. Also, widespread Quaternary volcanism within the "stable " area of central Papua New Guinea to the south of the mobile belt does not seem to affect the efficient transmission of high-frequency $(1 \mathrm{~Hz})$ shear energy.

The paths from events located along the New Hebrides, Solomon, and New Britain arcs to Australia traverse oceanic structure, and no $L g$ is observed from these paths. The inefficient propagation of $S_{n}$ along these paths from both shallow and intermediatc-depth events can be explained as follows: 1) For the New Hebrides case, the inefficiency of $S_{n}$ propagation for paths exceeding about $20^{\circ}$ distance is related to the relatively young age (Lower to Middle Eocene) of the suboceanic lithosphere of the Coral Sea. As proposed by CHINN, ISACKS and BARAZANGI (1979), such relatively thin lithosphere is probably not an efficient wave guide for shear energy of about $1 \mathrm{~Hz}$.2). The inefficiency of $\mathrm{Sn}$ propagation from events located along the northern Solomon and the New Britain 
arcs is probably due to anomalous attenuation in the uppermost mantle beneath the Woodlark basin and beneath southeastern Papua New Guinea. 3) The inefficiency of $S n$ propagation from events deeper than about $150 \mathrm{~km}$ located in the westernmost part of the northerly-dipping Benioff zone of the New Britain arc could be due either to structural isolation of the nearly vertical descending segment of the plate in which the events occur, or could be due to structural complexity of the plates in the region which interrupts the wave guide for $S n$ to the Australian stations. This structural feature could be the result of the collision of the Australian plate and the New Britain arc.

\section{INTRODUCTION.}

The Melanesian island arcs of New Hebrides, Solomon, New Britain, and Papua New Guinea, as well as the Banda arc, are amongst the seismically most active and complex plate boundaries on earth. The Australian plate descends beneath these arcs into the upper mantle, and the continental part of the Australian plae is in collision with the Papua New Guinea and Banda arcs. Among other things, this unusual situation provides an exceptional opportunitl to study the nature of propagation of high-frequency shear waves from sources at different depths and with varying amounts of oceanic and continental structures alcng the paths.

This paper concerns the relative excitation and propagation of the seismic shear waves $L g$ and $S n$ produced by earthquakes located along the Melanesian and Banda arcs and recorded at the two World-Wide Standardized Seismograph Network (WWSSN) stations of Charters Towers $(C T A)$ and Alice Springs $(A S P)$ located in Australia (see Figs. 1 and 2). Fortunately, these two stations are among the most sensitive stations of the world-wide network and have already produced large amounts of data on $L g$ and $S n$ that are available for examination. The distance from the sources to the stations varies from a minimum of about $12^{\circ}$ to a maximum of about $25^{\circ}$. In particular, we examine two aspects of $L g$ and $S n$. The first concerns the relative excitation of $L g$ and $S n$ as a function of the source depth. The propagation paths from Papua New Guinea-Banda sources to the CTA and ASP stations traverse the continental part of the Australian plate (the Arafura Sea is a very shallow sea with water depths that do not exceed about $200 \mathrm{~m}$ ). 


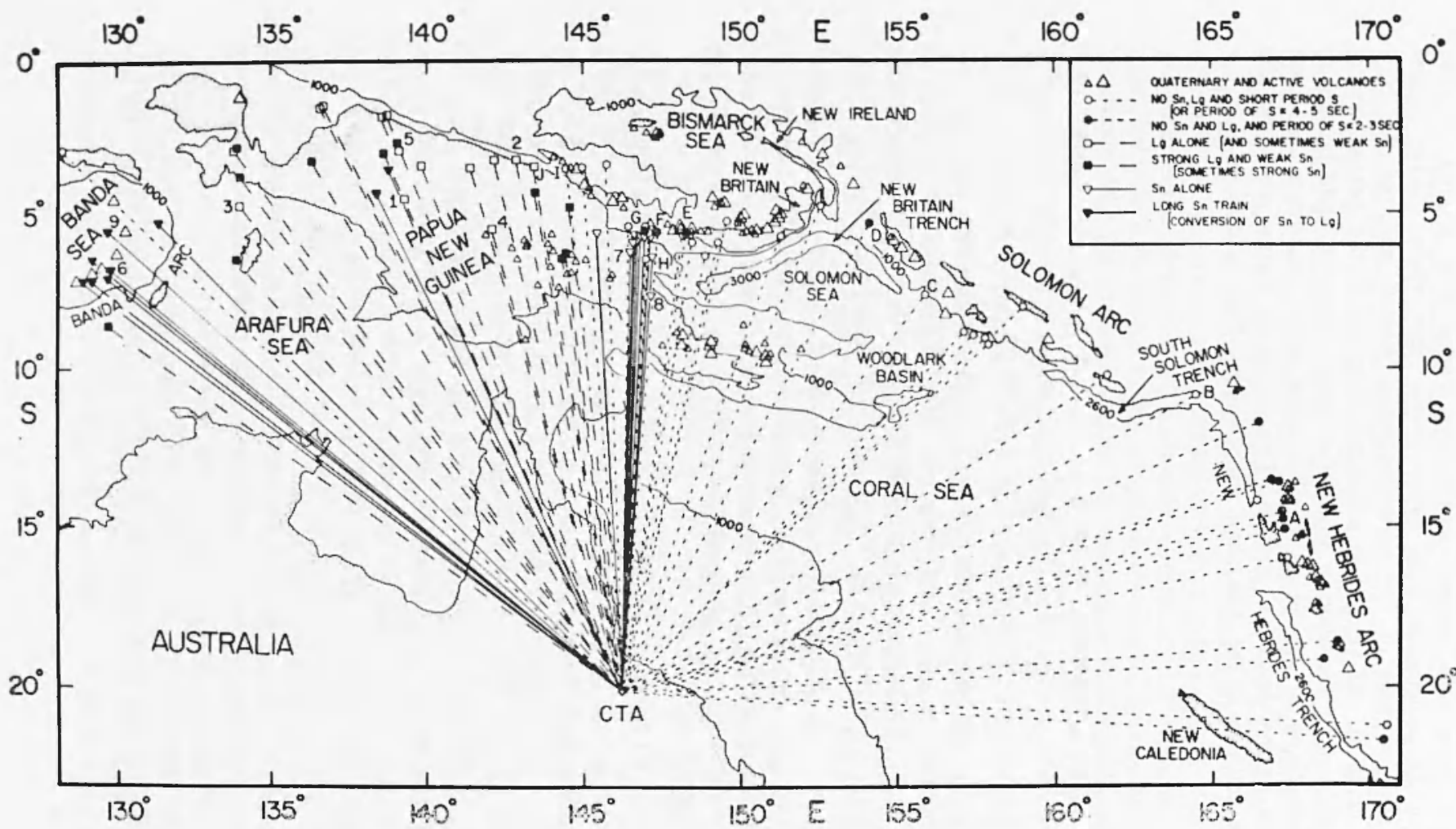

Fig. 1 Map of the southwest Pacific showing the Melanesian and Banda arcs and northeastern Australia. Selective contours of water depths are shown in fathoms. The 1000 fathoms' contour approximately marks the boundary of the continental lithosphere. Note that the Arafura Sea is a very shallow sea with water depths that do not exceed about 100 fathoms. Symbols' explanation is shown in the upper right hand corner of the figure, and see Fig. 5 for the depth distribution of the events used in this figure. This figure shows the results obtained at the Charters Towers (CTA) station in Australia. 


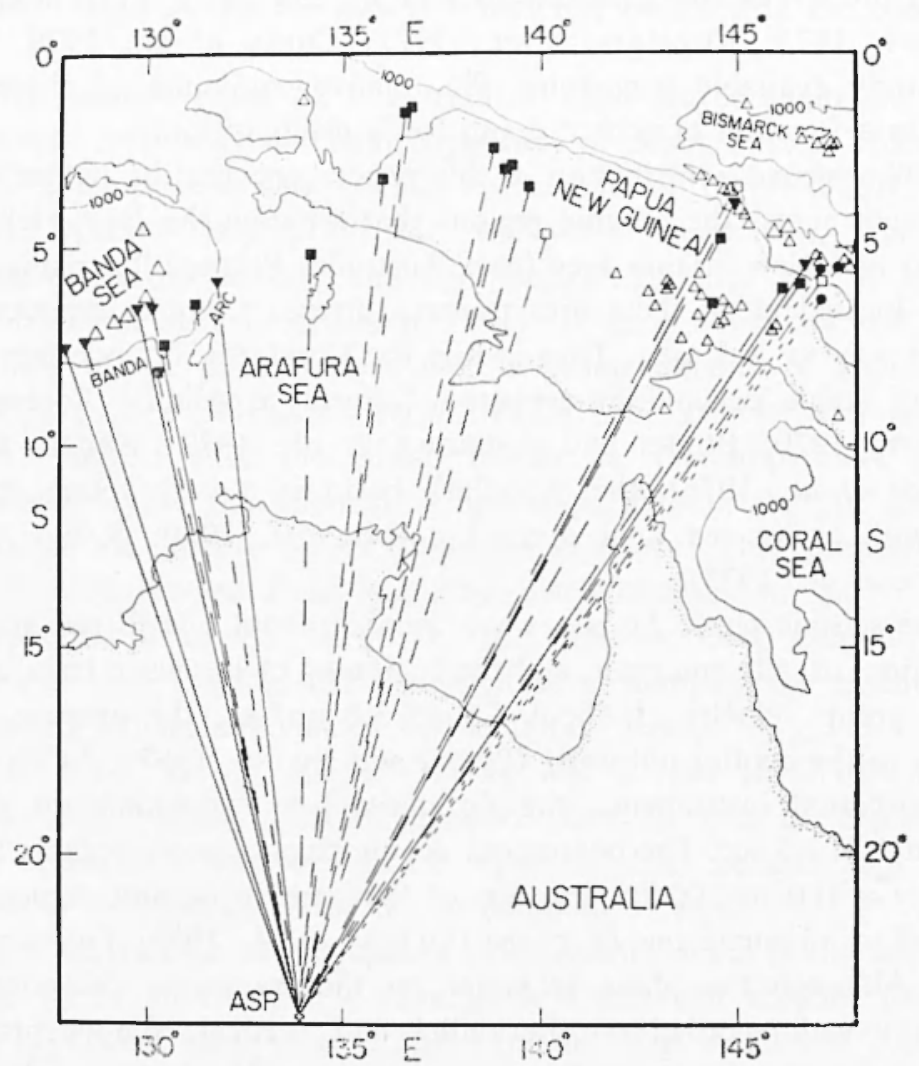

Fig. 2. Map showing some of the results obtained at the Alice Springs (ASP) station in Australia. Symbols are as in Figure 1.

The earthquakes along the Papua New Guinea collision boundary are distributed in about the upper $200 \mathrm{~km}$ of the earth along a diffuse but approximately vertical zone (see, for example, Denham, 1969; Johnson et al., 1971; Curtis, 1973 a). Earthquakes in the Banda arc define a well-determined Benioff zone that dips at about $50^{\circ}$ towards the Southeast Asia plate (CARDWELL and ISACKS, 1978). This geometry of the spatial distribution of shallow and intermediate-depth earthquakes relative to the continental Australian plate provides a unique opportunity to study the excitation of $L g$ and $S n$ as a function of source depth. Althcugh many studies are available in the literature that discuss 
different properlies and characteristics of $L g$ and $S n$ (e. g., Isacks and Stephens, 1975; Ruzaikin et al., 1977; ChinN et al., 1979, there is no study available concerning the relative excitation of these two phases as a function of source depth for a given region.

The second contribution of this paper concerns the nature of $S_{n}$ propagaticn across the oceanic regions that separate the New Hebrides, Solomon and New Britain ares from Australia. Propagation paths from sources located along these arcs traverse diverse tectonic environments on their way to Australia. Thus, while the Coral Sea is underlain by a relatively stable oceanic lithosphere of Early to Middle Eocene age (GARDNER, 1970; Burns and ANdrews et al., 1973; ANDrEws and PACKHAM et al., 1975), the Woodlark basin is a very young oceanic basin with active sea floor spreading (MILSOM, 1970; KARIG, 1972; LYENDYK et al., 1973).

The seismic phase $L g$ is a wave train of about one to two minutes in duration, usually emergent, and the beginning of the wave train travels with a group velocity of about 3.5 to $3.6 \mathrm{~km} / \mathrm{sec}$, the average shear velocity in the continental crust (PRESS and EwING, 1952). As recorded on short-period instruments, the $L g$ phase has a predominant period cf about 1 to $1.5 \mathrm{sec}$. The phase does not propagate across oceanic basins and cnly a 100 to $200 \mathrm{~km}$ segment of the path in oceanic structure is sufficient to eliminate the $L g$ phase (Oliver et al., 1955; EwING et al., 1957). Although the phase is larger on the transverse component it is usually well-recorded on the radial and vertical components. For continental paths, $L g$ is the largest and most striking seismic phase on the short-period records produced by shallow earthquakes located within the continental crust.

Oliver and Ewing (1957, $1958 \mathrm{a}$ and $1958 \mathrm{~b})$ and Kovach and ANDERSon (1964) proposed that $L g$ (as well as $S n$ ) represents higher modes of surface waves at short periods. Using normal mode theory they showed that a simple increase of velocity with depth in a continental crust forms an effective «wave guide" that is sufficient to explain the $L g$ phase without the need to assume crustal low-velocity channels, as had been previously proposed. Recently, KNopoff et al. (1973 and 1974) quantitatively demonstrated the validity of this interpretation using realistic source mechanisms and a realistic continental structure. They showed that group velocities of higher modes of Love waves at short periods are associated with amplitudes large enough to form the dominant $L g$ arrivals, and that particle displacement amplitudes 
of these higher mcdes are almost completely confined to the continental crust.

The seismic phase $S n$ is a train of shear waves about one minute in duration with a predominant frequency of about $1 \mathrm{~Hz}$ as recorded on the three component, short-period instruments of the WWSSN, though $S n$ is typically largest on the transverse component. The phase propagates across oceanic and continental structures and is observed to a maximum distance of about $35^{\circ}$ to $40^{\circ}$ (e. g., WALKER, 1977). The beginning of the phase travels with a group velocity of about 4.5 to $4.7 \mathrm{~km} / \mathrm{sec}$ (e. g., Huestis et al., 197j). The velocity and frequency content suggest that the phase travels in the uppermost part of the mantle above the attenuating low-velocity zone; that is, the phase travels in the mantle lid of lithospheric plates. This property made the phase quite useful in mapping discontinuities in the horizontal lithospheric plates on earth (e. g., Molnar and Oliver, 1969; BARAZANGI and IsACKS, 1971) as well as in mapping the extent of the descending lithospheric plates in the upper mantle (e. g., OLIVER and Isacks, 1967; Utsu, 1971). Oliver and Ewing (1958 b) and later BRune and Dorman (1963) suggested that $S n$ can be explained in terms of higher modes of surface waves at short periods in a manner similar to that proposed for the explanation of $\mathrm{Lg}$.

For the $S n$ case, an increase of velocity with depth in the uppermostmantle forms an effective "wave guide " that can account for $S n$ in terms of normal mode thecry. This explanation is in marked contrast to the proposal that the efficient propagation of $S n$ is due to low-velocity channels in the uppermost mantle (e. g., Shurbet, 1962 and 1964; Sutton and Wal.Ker, 1972). Recently, Stephens and ISACKs (1977) used theoretical studies based on a realistic earth structure to demonstrate quantitatively the validity of the explanation of $S n$ in terms of higher modes. They found that the particle displacement amplitudes of higher modes with group velocity near the $S_{n}$ velocity are mostly restricted to depths above the low-velocity zone of the upper mantle and are largest within the mantle lid of the lithosphere. Moreover, an important conclusion of heir study is that at periods longer than about 1.5 seconds, higher modes with group velocity near that of $S n$ have considerable particle displacements in the low-velocity, low $Q$ zone in the upper mantle and are, therefore, attenuated. This explains the observed predominanche of $S n$ frequencies of about $1 \mathrm{~Hz}$ and larger (IsACKs and 

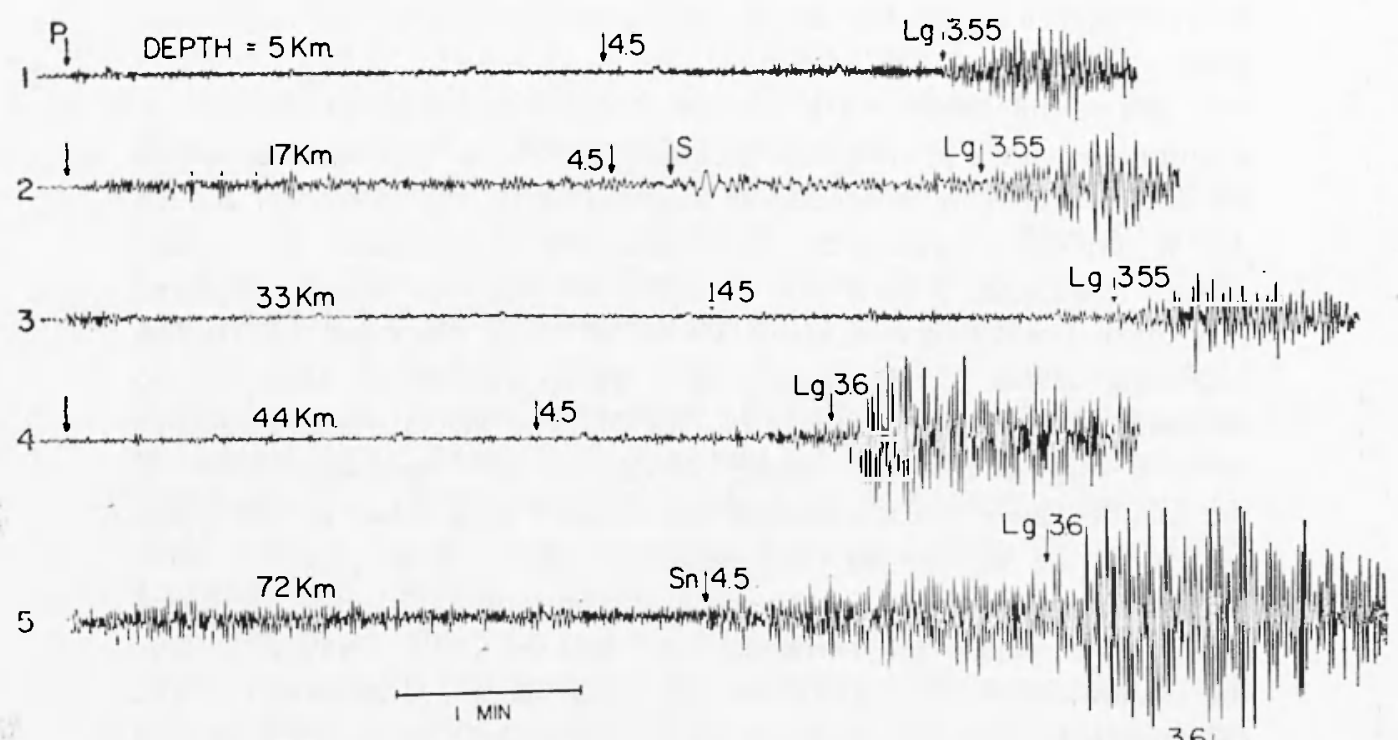

3.6

$106 \mathrm{Km} \quad \mathrm{Sn} 146$

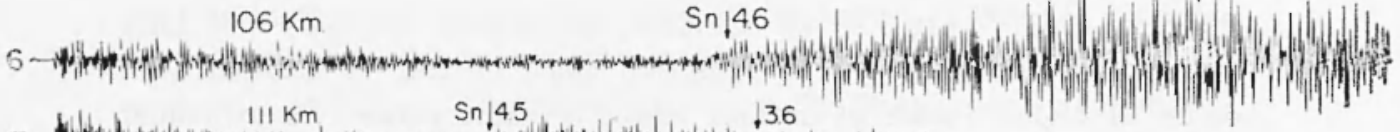

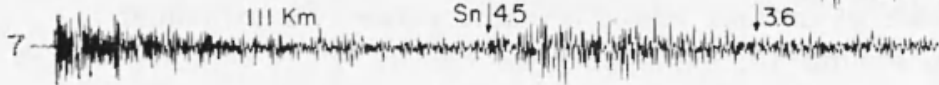

$135 \mathrm{Km} \quad \mathrm{Sn} ! 45 \quad 136$

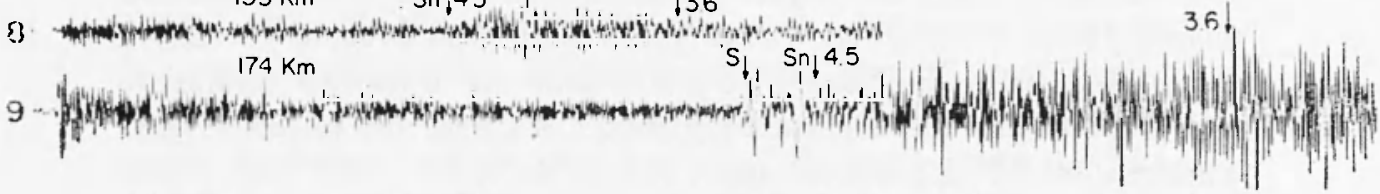

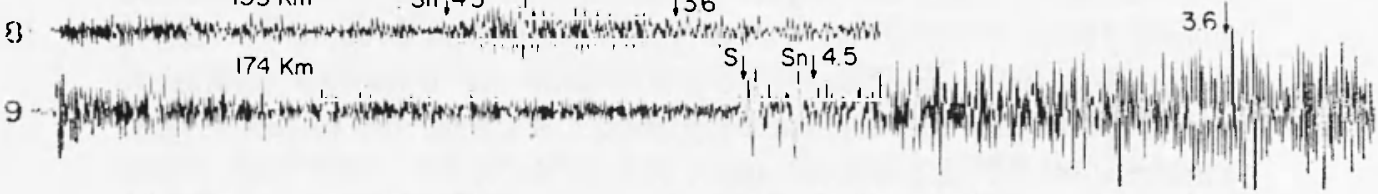

Fig. 3. Representative seismograms produced by shallow and intermediate depth earthquakes located along Papua New Guinea-Banda seismic zones and recorded at the CTA station in Australia. All records are produced by the horizontal components, short-period instruments. See Table 1 lor the parameters of the events that produced these records, and see Fig. 1 for the locations of the events. The records are arranged in increasing depths. The group velocities (in $\mathrm{km} / \mathrm{sec}$ ) and identification of $L g$ and $S n$ phases are shown on the records. Note that for the four shallow events only $L g$ phase is recorded. As the depth of events increases, the $S n$ phase is also recorded; and for events deeper than about $100 \mathrm{~km}$ the train of seismic encrgy that follows $S n$ continues for more than four minutes. well beyond the expected arrival time of the $L g$ phase. This could be explained by the conversion of $S n$ into $L g$ along the propagation path and the subsequent propagation of Lg within the crustal wave guide. Note that records 7 and 8 show only short-duration $S_{n}$ phases since the propagation paths from these two events traverse oceanic structure. 
TABLE 1. Parameters (1) of earthquakes shown in Figures 3 and 6.

\begin{tabular}{|c|c|c|c|c|c|c|c|c|c|}
\hline \multirow{2}{*}{\multicolumn{2}{|c|}{$\begin{array}{l}\text { Earthquake } \\
\text { Number }\end{array}$}} & \multirow{3}{*}{$\begin{array}{c}\text { Date } \\
26,1968\end{array}$} & \multirow{3}{*}{$\begin{array}{l}\text { Origin Time } \\
\text { hr.: min.: sec. } \\
\text { 16: } 25: 46\end{array}$} & \multirow{3}{*}{$\begin{array}{l}\text { Latitude }^{0} \\
\frac{S}{4.50}\end{array}$} & \multirow{3}{*}{$\begin{array}{l}\text { Longitude }^{0}, \\
139.30\end{array}$} & \multirow{3}{*}{$\begin{array}{l}\begin{array}{c}\text { Depth } \\
\text { Km }\end{array} \\
5\end{array}$} & \multirow{3}{*}{$\begin{array}{l}\text { Distance } \\
\left(\Delta^{0}\right) \text { to } C T A E \\
16.90\end{array}$} & \multirow{2}{*}{$\begin{array}{l}\text { Azimuth } \\
\text { to } C T A \\
\text { of } N\end{array}$} & \multirow{3}{*}{$\begin{array}{l}\text { Component } \\
\text { at } C T A \\
E-W\end{array}$} \\
\hline & & & & & & & & & \\
\hline 1 & Sept. & & & & & & & 157 & \\
\hline 2 & June & 9,1969 & $06: 51: 15$ & 3.26 & 142.91 & 17 & 17.04 & 169 & $E-W$ \\
\hline 3 & Nov. & 3. 1965 & $07: 34: 10.9$ & 4.70 & 134.00 & 33 & 19.40 & 143 & $E-W$ \\
\hline 4 & Nov. & 10,1969 & $15: 42: 35.1$ & 5.57 & 142.06 & 44 & 15.00 & 165 & $E-W$ \\
\hline 5 & July & 2. 1968 & $18: 40: 11.3$ & 2.70 & 139.01 & 72 & 18.67 & 158 & $E-W$ \\
\hline 6 & Jan. & 4,1969 , & $22: 36: 47.9$ & 6.80 & 129.79 & 106 & 20.73 & 131 & $E-W$ \\
\hline 7 & Jan. & 7,1969 & $01: 14: 15.6$ & 6.20 & 146.44 & 111 & 13.80 & 181 & $E-W$ \\
\hline 8 & Sept. & 3,1967 & $01: 23: 19.7$ & 7.78 & 147.12 & 135 & 12.27 & 184 & $E-W$ \\
\hline 9 & Apr. & 20,1967 & $00: 01: 26.1$ & 5.57 & 129.71 & 174 & 21.61 & 133 & $E-W$ \\
\hline$A$ & July & 29,1969 & $06: 24: 22.7$ & 14.84 & 167.30 & 128 & 20.73 & 252 & $N-S$ \\
\hline$B$ & Jan. & 14,1969 & $12: 35: 35$ & 10.85 & 164.48 & 16 & 19.81 & 240 & $N-S$ \\
\hline C & Aug. & 22,1969 & $15: 45: 05.9$ & 7.59 & 155.92 & 82 & 15.56 & 216 & $E-W$ \\
\hline$D$ & Aug. & 7,1969 & $01: 49: 32.9$ & 5.26 & 154.06 & 116 & 16.58 & 207 & $E-W$ \\
\hline$E$ & Aug. & 30,1969 & $12: 51: 57.5$ & 5.63 & 148.29 & 162 & 14.50 & 188 & $N-S$ \\
\hline$F$ & Sept. & 1,1967 & $03: 31: 10.9$ & 5.56 & 147.18 & 184 & 14.47 & 183 & $N-S$ \\
\hline$G$ & Apr. & 13,1968 & $17: 33: 11.2$ & 5.43 & 146.92 & 226 & 14.58 & 182 & $N-S$ \\
\hline$H$ & Aug. & 2. 1969 & $04: 30: 32$ & 6.52 & 146.92 & 33 & 13.51 & 183 & $E-W$ \\
\hline$I$ & Aug. & 15, 1969 & $03: 37: 52.9$ & 3.45 & 144.39 & 22 & 16.64 & 174 & $N-S$ \\
\hline I & Oct. & 24,1968 & $02: 02: 25$ & 3.43 & 143.42 & 25 & 16.78 & 171 & $E-W$ \\
\hline
\end{tabular}

(1) All parameters are those reported by the Bulletins of the International Seismological Centre (ISC). 
Oliver, 1964; Sutton and Walker, 1972; IsACKs and StePhens, 1975).

The explanation of $L g$ and $S n$ waves in terms of higher modes of surface waves predicts that excitation of these waves should be the; strongest when the source is located in the crust for the Lg phase and when the source is located in the mantle lid of the lithosphere for the $S n$ phase. In this paper we present observations that support the above explanation.

The locations and the origin times of the events used in this study are those reported in the Bulletins of the International Seismological Centre $(I S C)$. The body-wave magnitude of the events used varies from about 4.5 to 6.0 . For every event used we examined all three components of the short-period records and searched for the existence or absence of $L g$ and $S n$ phases. If the phases are recorded the group velocities of the first arrivals are determined, otherwise the expected time of arrivals using the determined $L g$ and $S n$ velocities are marked (see Fig. 3 and Table 1). We obtained $L g$ and $S n$ velocities that vary from 3.5 to 3.6 and from 4.5 to $4.6 \mathrm{~km} / \mathrm{sec}$, respectively. For any given propagation path, we have examined enough data to establish unambiguously a clear pattern. Moreover, data from the $A S P$ station are examined to document the validity and the pattern of observations as obtained from the extensive data of the $C T A$ station.

Relative excitation of $L g$ and $S n$ as a function of source Depth.

The most striking observation in this study is the predominance of the $L g$ phase on the short-period records of $C T A$ and $A S P$, especially the transverse component, produced by events located in about the upper $40 \mathrm{~km}$ of earth, in comparison with other seismic phases (see Fig. 3). The observed $L g$ is of ten emergent and has a duration of about two minutes. For events deeper than about $40 \mathrm{~km}$, a weak but clear $S n$ arrival is observed on the short-period records (see Fig. 3). Figure 4 clearly shows that the ratio of the maximum amplitudes of $L g$ and $S n$ phases as measured on the transverse component relative to the maximum $p$ amplitudes as measured on the vertical component is on the average about three times larger for the $L g$ case in comparison to the $S n$ case. This suggests that either the $L g$ crustal wave guide is a more efficient 


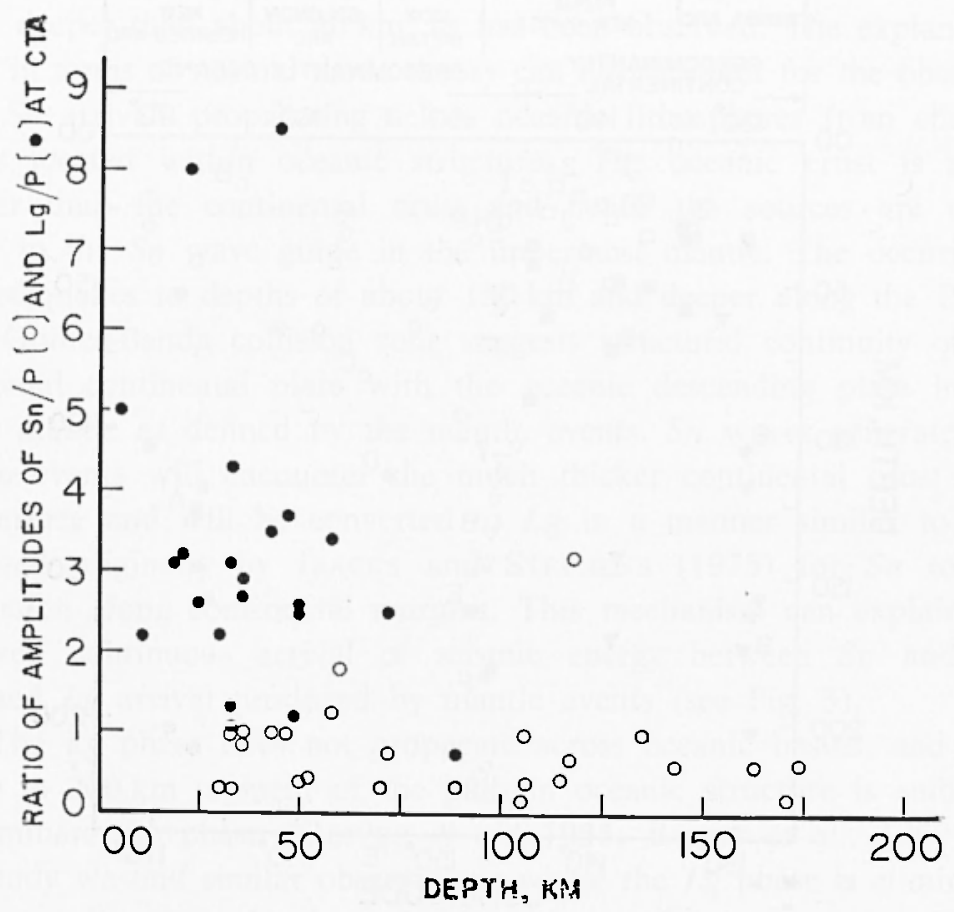

Fig. 4. This figure clearly shows that the ratio of the maximum amplitudes of $\mathrm{Lg}$ and $S_{n}$ phases as measured on the transverse component relative to the maximum $P$ amplitudes as measured on the vertical components versus depth of events is on the average about three times larger for the $\mathrm{Lg}$ case in comparison to the $S n$ case. These observations suggest that either the $L g$ crustal wave guide is a more efficient one than the uppermost mantle wave guide of $S n$, or that $L g$ is better excited than $S n$.

one than the uppermost mantle wave guide of $S n$, or that $L g$ is more easily excited than $S n$. Records produced by events deeper than about $70 \mathrm{~km}$ show large $S n$ arrivals and the train of seismic energy that follows $S_{n}$ continues for more than four minutes, well beyond the expected arrival time of the $L g$ phase (see Figs. 3 and 5). Thus no distinctly separated $L g$ and $S n$ phases are recorded from events deeper than about $70 \mathrm{~km}$. The ccntinuous recording of seismic waves after the $S n$ arrival could be explained by the conversion of $S n$ into $L g$ along the propagation 


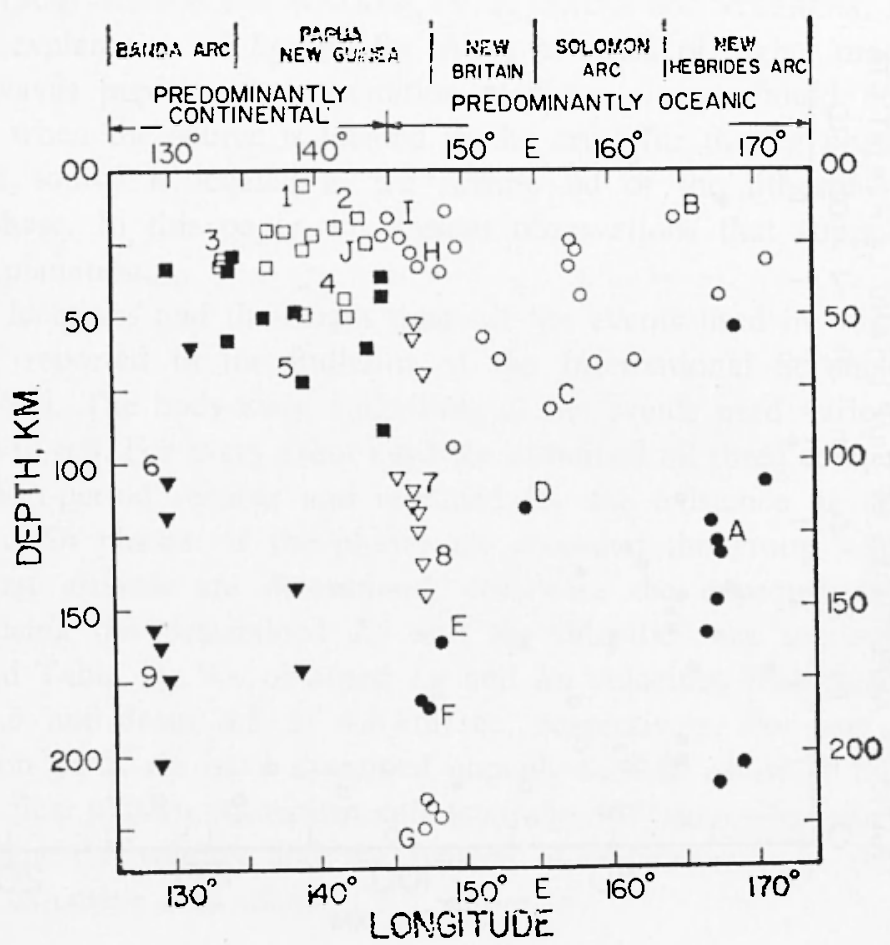

Fig. 5. Cross section showing the projection of the diflerent physiographic features used in this study along an east-west azimuth versus the depth of events associated with these features. Symbols are as in Fig. 1. Events that produced the records of Figures 3 and 6 are indicated by letters and numbers.

path and the subsequent propagation of $L g$ within the crustal wave guide (see Isacks and Stephens, 1975; CKinn et al., 1979).

The above observations are in agreemeit with the quantitative explanations of $L g$ and $S n$ in terms of normal mode theory. Since the particle displacement amplitudes of the higher modes of surface waves that make up the $L g$ phase are largely restricted to the crust (KNopofF et al., 1973), and since the continental crust beneath the Australian shelf is about $35 \mathrm{~km}$ thick (JACOBSON and SHor, 1977), then $L g$ will be excited most efficiently by sources located within the crust, as we have observed. The particle displacement amplitudes of the higher modes of surface waves that make up the $S n$ phase are largely restricted to the uppermost mantle (STEPHENS and ISACKS, 1977), and therefore, 
$S_{n}$ is excited very efficiently by sources in the uppermost mantle and hence deeper than about $40 \mathrm{~km}$, as has been observed. The explanation of $S n$ in terms of normal mode theory can also account for the observed large $S n$ arrivals propagating across oceanic lithospheres from shallow events located within oceanic structures. The oceanic crust is much thinner than the continental crust and hence the sources are much closer to the $S_{n}$ wave guide in the uppermost mantle. The occurrence of earthquakes to depths of about $150 \mathrm{~km}$ and deeper along the Papua New Guinea-Banda collision zone suggests structural continuity of the horizontal continental plate with the oceanic descending plate in the upper mantle as defined by the mantle events. Sn waves generated by mantle events will encounter the much thicker continental crust near the surface and will be converted to $L g$ in a manner similar to that proposed originally by Isacks and Stephens (1975) for $S n$ to $L g$. conversion along continental margins. This mechanism can explain the observed continuous arrival of seismic energy between $S_{n}$ and the expected $L g$ arrival produced by mantle events (see Fig. 3 ).

The $L g$ phase does not propagate across oceanic basins, and only a 100 to $200 \mathrm{~km}$ segment of the path in oceanic structure is sufficient to eliminate the phase (Oliver et al., 1955; Ewing et al., 1957). In this study we find similar observations where the $L g$ phase is eliminated by propagation in only about $200 \mathrm{~km}$ of oceanic structure (as defined by water depths greater than about $2 \mathrm{~km}$ ) that exists between eastern Papua New Guinea and northeastern Australia (see Figs. 1 and 3). Moreover, the sudden disappearance of the $L g$ phase as found in this study (see, for example, records $I$ and $J$ in Fig. 6) suggests that there must be a critical distance for $L g$ propagation in the oceanic structure beyond which $L g$ is eliminated. This observation must be explained by any quantitative study of the lack of $L g$ transmission across oceanic structures.

It is worth noting here that $L g$ and $S n$ phases are efficiently trasmitted across central Papua New Guinea where numerous (more than sixteen) stratovolcanoes of Quaternary age are scattered through a region of about $200 \mathrm{~km}$ in width and about $400 \mathrm{~km}$ in length (see Fig. 1). Basaltic rocks are dominant in eleven volcanoes, and andesitic-type rocks are dominant in the rest of the volcanoes (MacKenzie, 1976). The tectonic significance of these volcanoes is not understood since they are underlain by relatively stable old continental crust and the initiation of volcanism in early Pliocene is much more recent than the last episode 

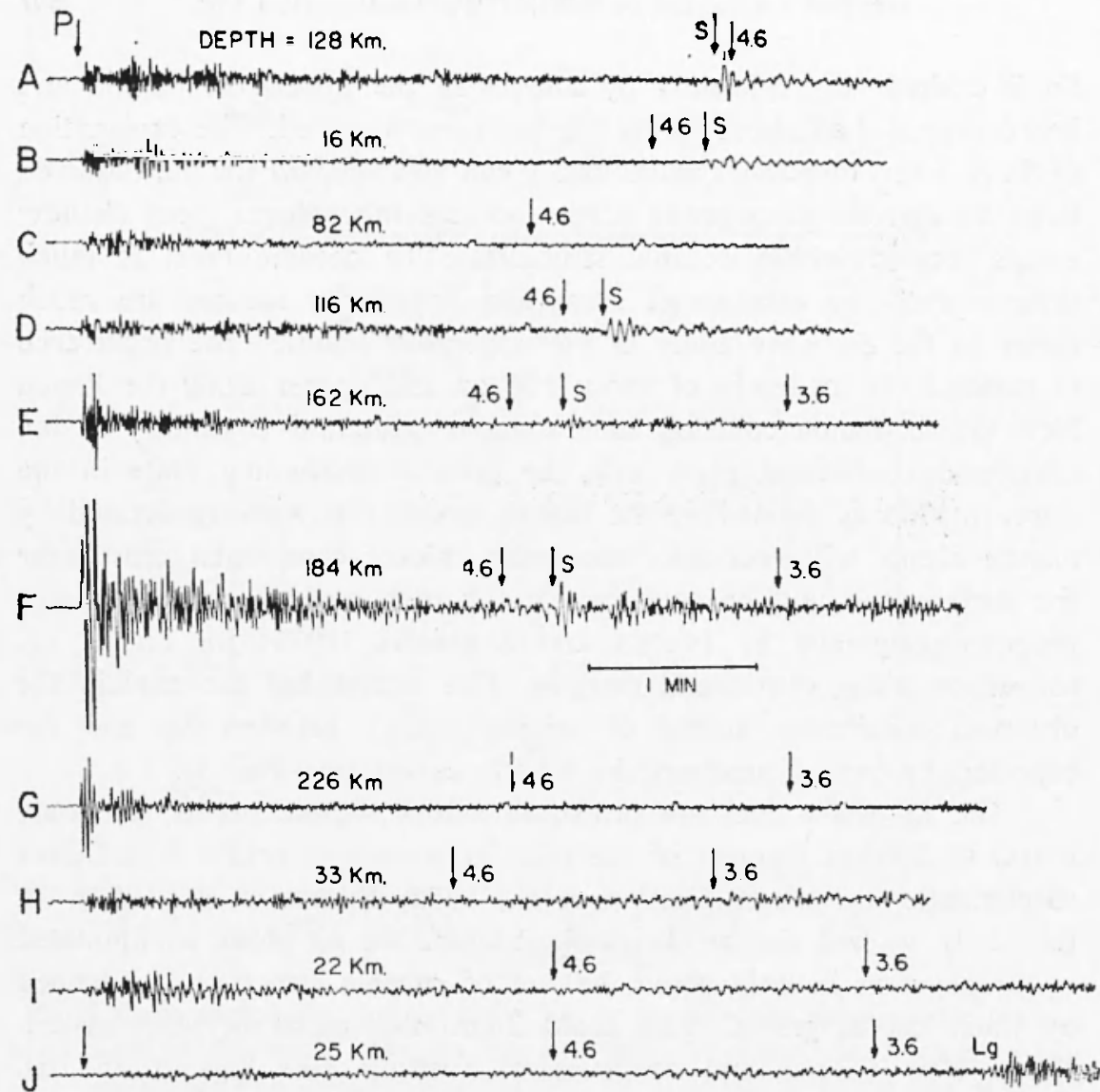

Fig. 6. Representative seismograms produced by shallow and intermediate depth earthquakes located along the New Hebrides, Solomon, New Britain, and Papua New Guinea seismic zones and recorded at the CTA station in Australia. All records are produced by the horizontal components, shortperiod instruments. See Table 1 for the parameters of the events that produced these records, and see Fig. 1 for the locations of the events. The group velocities (in $\mathrm{km} / \mathrm{sec}$ ) of the expected beginning of $L g$ and $S n$ phases are indicated on the records. Inefficient $S n$ propagation from events $A$ and $B$ is related to the relatively young age of the suboceanic lithosphere of the Coral Sea. Inefficient $S n$ propagation from events $C, D$, and $E$ is due to anomalous attenuation in the uppermost mantle beneath the Woodlark basin and beneath southeastern Papua New Guinea. Inefficient $S n$ propagation from the intermediate depth events $F$ and $G$ is due either to structural isolation of the plate in which the events occur, or to structural complexity of the plates near the collision zone that interrupts the $S n$ wave guide. This is in contrast to the efficient $S_{n}$ propagation from the intermediate depth events located just south of the vertical zone (see records 7 and 8 in Fig. 3 , and sec also Fig. 7 b). Sn phase is not efficiently exicited by shallow crustal events (records $H, I$ and $J$ ), and $L g$ is not recorded from events $H$ and $I$ since the propagation paths traverse an oceanic structure. However, when the length of the scgment of the path crossing oceanic structure is less than about $200 \mathrm{~km} \mathrm{Lg}$ is well recorded (record $J$ ). 
of collision in early Miocene between the northern margin of Papua New Guinea and the New Britain arc (e. g., MacKenzie, 1976; JoHnSON, 1976). The transmission of high-frequency shear waves across this region suggests that there is no wide-spread zone of partially melted material in the crust or the uppermost mantle beneath the volcanoes to attenuate these waves.

INEFFICIENT PROPAGATION OF $S n$ FROM NEW HEBRIDES, SOLOMON AND NEw Britain arcs to Australia.

Inefficient Propagation of Sn and the Age of the Lithosphere.

Abundant data clearly show that $S n$ is not transmitted across the Coral Sea to the CTA station from shallow and intermediate depth events located along the New Hebrides and the southern part of the Solcmon arcs (see Figs. 1 and 6, and Table 1).

The distance from these events to the CTA station varies from about $18^{0}$ to $25^{\circ}$. Molnar and Oliver (1969) were the first to report this "anomalous " inefficient $S n$ propagation in the Coral Sea; the observations do not lit the global pattern of $S n$ propagation, as mapped by Molnar and Oliver, in which the lithospheric regions in front of island arcs transmit $S_{n}$ very efficiently, as in the western Pacific regions in front of the Tonga-Kermadec arc (Oliver and IsACKS, 1967; BARAZANG et al., 1972) and in front of the Bonin-Mariana arc (Sutton and Walker, 1972; Walker, 1977). Barazangl et al., (1974) showed that $S n$ propagates very efficiently along a $400 \mathrm{~km}$ wide region just to the west of the New Hebrides trench. As the Coral Sea region is for the most part of Early to Middle Eocene in age and has no cbvious recently active tectonic structures that may be associated with ancmalous attenuation in the uppermost mantle, the observations of inefficient transmission of $S n$ remained unexplained. However, two recent studies by STEPHENS and IsACKs (1977) and ChinN et al., 1979, produced results that may help to explain the above observations. CHINN et al., observed that $S_{n}$ propagates efficicntly only to a maximum distance of about $15^{\circ}$ along the eastern part of the Nazca plate. The Eocene age (about 50 to $60 \mathrm{~m}$. y) of this segment of the Nazca plate is comparable to that of the Coral Sea. This contrasts with efficient $S n$ 
propagation for distances beyond $50^{\circ}$ in the western Pacific (Walker, 1977) which has a Mesozoic age $(>130 \mathrm{~m} . \mathrm{y}$.). Thus, there seems to be a relationship between the maximum distance along which $S n$ propagates efficiently and the age, and hence the thickness, of the oceanic plates.

STEPHENS and ISACKS (1977) quantitatively explained $S n$ in terms of higher modes of surface waves. An important conclusion of their study is that for the oceanic structure they used, which has a $60 \mathrm{~km}$ thick lithosphere on top of a low velocity-low $Q$ zone, higher modes with group velocity near $S n$ velocity and with periods longer than about 1.5 seconds have a considerable particle displacement in the low $Q$ zone and are therefore subject to severe attenuation. This explains the predominance of high frequency waves $(1 \mathrm{~Hz}$ and higher) associated with $S n$, though in our study $S n$ waves have a predominant frequency of only about $1 \mathrm{~Hz}$ since the response of the short-period WWSSN instruments is peaked around $1 \mathrm{~Hz}$. This conclusion of STEPHENS and IsACKS may qualitatively explain the observed inefficient transmission of $S n$ across the Coral Sea. The thickness of a lithospheric plate with the age of the Coral Sea may be less by about a factor of 1.5 than the older western Pacific plate (Yoshi et al., 1976; Schubert et al., 1976; Turcotte and Oxвurgh, 1978). Thus, for the thinner lithospheres of the Coral Sea and the Nazca plate, the $1 \mathrm{~Hz}$ component of higher modes of surface waves that make up $S n$ may have a substantial particle displacement in the low $Q$ zone and are therefore attenuated if $S n$ propagates beyond a critical distance. If this explanation is correct then it predicts that for a given lithosphere the higher frequency components of $S n$ will travel farther and more efficiently than the lower frequency components. The results of WALKER (1977) regarding $S n$ propagation in the Ontong Java plateau are in agreement with this prediction.

It must be mentioned here, however, that recent data on heat flow and magnetic anomalies in the eastern part of the Coral Sea (e. g., LARUe et al., 1977) suggest the existence of a fossil spreading center in the region of an Oligocene age (about $30 \mathrm{~m}$. y.). If anomalous uppermost mantle material still exists beneath this fossil feature, then it is possible to explain some of the inefficient $S n$ observations as due to propagation across this anomalous material. 
Inefficient Propagation of Sn Across the Woodlark Basin and Southeastern Papua New Guinea.

Geological and geophysical data show that the Woodlark basin is a recently active marginal basin which is extensional in origin (MILSOM, 1970; Karig, 1972; LuYENDYK et al., 1973). This tectonic environement is usually associated with a zone of anomalous high attenuation, or low $Q$ in the uppermost mantle beneath the basin (see, for example, BARAZANGI and ISACKs, 1971, for a detailed study of the Lau basin behind the Tonga island arc). Thus, the observed inefficient transmission of $S n$ across the basin (see Fig. 1) suggests the presence of an anomalously low $Q$ zone beneath the Woodlark basin.

A major feature of the geology and structure of southeastern Papua New Guinea (the Papuan peninsula) is the ultramafic belt, an ophiolite suite of rocks considered to result from the collision of continental crust with an active island arc during the late Eocene (e. g.. Davies and SMitil, 1971; Karig, 1972; Milson, 1973). Extensive volcanism started in the late Miocene on the Papuan peninsula and off-shore islands (JOHNSON et al., 1973) and is still active to the present time (see Fig. 1). The tectonic significance of this recent episode of volcanism is not understood. It could, however, be related to the extensional tectonics predominant in the adjacent Woodlark basin, and therefore, an anomalous low $Q$ zone in the uppermost mantle may exist beneath the peninsula that may be responsible for the observed inefficient propagation of $\mathrm{Sn}$.

Inefficient Propagation of Sn From Mantle Earthquakes Located Along the Collision Zone Between the Australian Plate and New Britain Arc.

The geology and structure of northern Papua New Guinea are influenced to a large extent by the collision, starting in the Miocene, of the continental part of the Australian plate with the Melanesian arc systems (e. g., Dewey and Bird, 1970; Coleman, 1971; Karig, 1972; CURTIS, $1973 \mathrm{~b}$; JoHNSON, 1976). The effects of the collision process has currently reached the northeastern part of Papua New Guinea along the western edge of the New Britain arc (see Fig. 1). Although the northerly dipping Benioff zone beneath the New Britain arc is well-defined, the structure of the region along the collision zone is 
very complex and many tectonic models are proposed to describe the deep structure of the region (see, for example, Johnson and MoLnAR, 1972; JoHNSON, 1976). A major controversy concerns the existence, beneath the region, of a well-defined descending lithospheric plate which is continucus with a horizontal lithosphere, and what is the polarity of such a descending plate.

The spatial distribution of earthquakes beneach the region (see Fig. 7) does not delineate a well-defined Benioff zone in about the upper $150 \mathrm{~km}$ of earth; the data can be interpreted to suggest either a southwesterly or a north-easterly dipping Benioff zone (e. g., Denham, 1969; Johnson et al., 1971; Curtis, 1973 a). However, a striking feature of the spatial distribution of earthquakes is the near vertical cluster of events between depths of about 150 and $250 \mathrm{~km}$. These events appear to be isolated from the diffuse pattern of hypocenters to the south and also appear to be separated from the well-defined northerly dipping Benioff zone beneath the New Britain arc to the east (see Fig. 7 from Johnson et al., 1971).

In this study we observed that $S n$ waves are transmitted very efficiently to Australia from subcrustal events located in the diffuse pattern of hypocenters beneath northeast Papua New Guinea (see Figs. 3 and 5). However, no $S_{n}$ is observed from the events located in the nearly vertical cluster of events. These observations may indicate that the plate segment as defined by the vertical cluster of events is structurally isolated in the upper mantle from any horizontal lithosphere on the surface. Thus, $S n$ waves from these events would have to travel high-frequency shear waves and hence interrupts the $S n$ wave guide to a short distance through the low $Q$ asthenosphere which attenuates the the Australian stations. It is possible that the isolated segment of slab was part of the northerly dipping slab that exists beneath the New Britain arc but is now detached from it as a result of the collision of the continental Australian plate and the New Britain arc.

An a!ternative explanation for the inefficient propagation of $S n$ from the mantle events located in the nearly vertical cluster of events could be due to deep structural complexity of the plates along the collision zone. This structural complexity may prohibit the channelling of Sn-type waves into the horizontal lithosphere and hence interrupts the wave guide for $S n$ to the Australian stations. 


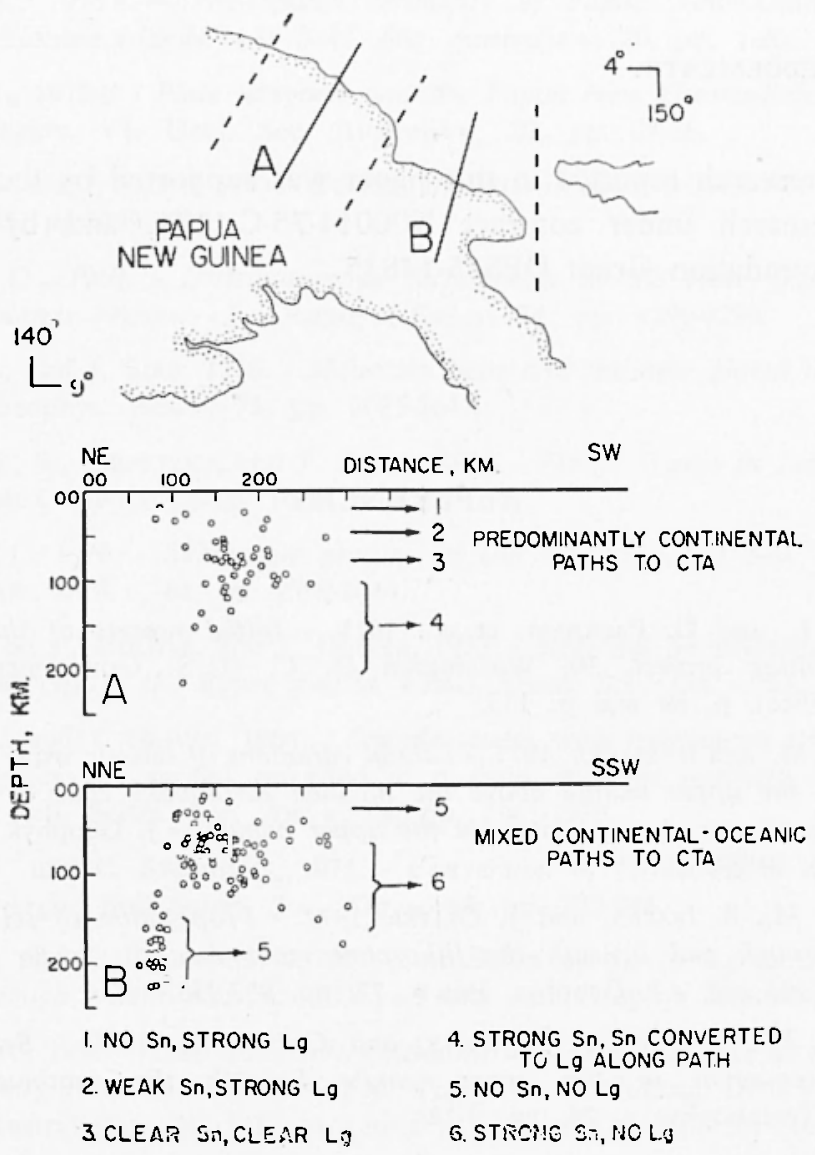

Fig. 7. Two cross-sections showing the distribution of hypocenters in the upper $200 \mathrm{~km}$ of earth along the northern part of Papua New Guinea (section A) and along the northeastern part of Papua New Guinea close to the western edge of the New Britain arc (section B). The two sections arc adopted from Johnson et al. (1971). The nature of $L g$ and $S n$ propagation as recorded at the CTA station is indicated by numbers which are explained at the bottom of the figure. Number 1 is represented by records 1,2,3, and 4 of Fig. 3; number 3 is represented by record 5 of Fig. 3; number 4 is represented by records 6 and 9 of Fig. 3; number 5 is represented by the records of Fig. 6 (except record J); and finally number 6 is represented by records 7 and 8 of Fig. 3. Note the near vertical cluster of events between depths of about 150 and $250 \mathrm{~km}$ in section B. These events appear to be isolated from the diffuse pattern of hypocenters to the south and may indicate that the descending plate segment defined by these events is structurally isolated in the upper mantle from any horizontal lithosphere on the surface. 


\section{ACKNOWLEDGEMENTS.}

The research reported in this paper was supported by the Office of Naval Research under contract N00014-75-C-1121, and by National Science Foundation Grant DES75-14815.

\section{REFERENCES}

ANdrEWS, J.. and G. PACKHAM, et al., 1975. - Initial reports of the deep sea drilling project, 30, Washington D. C. (U.S. Government Printing Office), p. 69 and p. 133.

BARAZANGI, M., and B. ISACKS, 1971. - Lateral variations of seismic wave attenuation in the upper mantle above the inclined earthquake zone of the Tonga island arc: deep anomaly in the upper mantle. "J. Geophys. Res.," 76. pp. 8493-8516.

Barazangi, M., B. Isacks, and J. Oliver, 1972. - Propagation of seismic waves through and beneath the lithosphere that descends under the Tonga island arc. "J. Geophys. Res.», 77, pp. 952-958.

Barazangi, M., B. Isacks, J. Dubols, and G. Pascal, 1974. - Seismic wave attenuation in the upper mantle beneath the southwest Pacific. "Tectonophys. », 24, pp. 1-12.

Brune, J., and J. Dorman, 1963. - Seismic waves and earth structure in the Canadian shield. "Bull. Seism. Soc. Am. ", 53, pp. 167-209.

Burns, R., and J. Andrews, et al., 1973. - Initial reports of the deep sea drilling project, 21, Washington D. C., (U. S. Government Printing Office), p. 369.

CARdwell, R., and B. Isacks, 1978. - Geometry of the subducted lithosphere beneath the Banda sea in eastern Indonesia from seismicity and faultplane solutions. " J. Geophys. Res. », 83, pp. 2825-2838.

Chinn, D., B. Isacks, and M. Barazangi, 1979, High-frequency wave propagation in tvestern South America along the continental margin, in the Nazca plate, and across the Altiplano, "Geophys. J. R. astr. Soc.", in press.

Coleman. R., 1971. - Plate tectonic emplacement of upper mantle peridotites along continental edges. "J. Geophys. Res.», 76, pp. 1212-1222. 
Curtis, I., 1973 a. - The spatial seismicity of Papua New Guinea and the Solomon islands. «J. Geol. Soc. Australia », 20, pp. 1-20.

Curtis, J., $1973 \mathrm{~b}$ - Plate tectonics and the Papua New Guinea-Solomon islands region. "J. Geol. Soc. Australia ", 20, pp. 21-36.

Davies, H., and I. Smith, 1971. - Geology of eastern Papıa. "Geol. Soc. Am. Bull.», 82, pp.3299-3312.

Denham, D., 1969. - Distribution of earthquakes in the New Guinea-Solomon islands region. «J. Geophys. Res.», 74, pp. 4290-4299.

DEWEY, J., and J. BIRD, 1970. - Mountain belts and the new global tectonics. «J. Geophys. Res. », 75, pp. 2625-2647.

Ewing, M., W. Jardetzky, and F. Press, 1957. - Elasic Waves in Layered Media. Mc Graw-Hill, New Jork.

Gardner, J., 1970. - Submarine geology of the western Coral Sea. «Geol. Soc. Am. Bull. », 81, pp. 2599-2614.

Huestis, S., P. Molnar, and J. Oliver, 197j. - Regional Sn velocities and shear velocity in the upper mantle. "Bull. Seism. Soc. Am. ", 63, pp. 469-475.

ISACKs, B., and J. OLIVER, 1964. - Seismic waves with frequencies from 1 to 100 cycles per second recorded in a deep mine in northern New Jersey. «Bull. Seism. Soc. Am.», 54, pp. 1941-1979.

ISAcks, B., and C. Stemhens, 1975. - Conversion of Sn to $\mathrm{Lg}$ at a continental margin. Bull Seism. Soc. Am. », 65, pp. 235-244.

IsACK, B., and C. StePHens. 1975. - Conversion of Sn to Lg at a continental trough system. Abstract, EOS, “Trans. Am. Geophys. Union », 58, p. 1186.

Johnson, R., 1976. - Late Cainozoic volcanism and plate tectonics at the southern margin of the Bismarck Sea, Papua New Guinea. In "Volcanism in Australasia ", R. Johnson (editor), Elsevier Co., pp. 101-116.

Johnson, R., D. Mac Kenzie, and I. Smith, 1971. - Seismicity and late Cenozoic volcanism in parts of Papua New Guinea. "Tectonophys", 12, pp. 15-22.

Johnson, R., D. Mac Kenzie, I. Smith, and G. TAylor, 1973. - Disiribution and petrology of late Cenozoic volcanoes in Papua New Guinea. In "The Western Pacific: Island Arcs, Marginal Seas, Geochemistry », P. Coleman (editor), Univ. W. Aust. Press, pp. 523-533.

Johnson, T., and P. Molnar, 1972. - Focal mechanisms and plate tectonics of the south-11'est Pacific, "J. Geophys. Res.", 77. pp. 5000-5032.

Karic, D., 1972. - Remnant arcs. "Geol. Soc. Am. Bull. ", 83, pp. 1057-1068.

Knopoff, L., F. Schwab, and E. Kausel, 1973. - Interpretation of Lg, "Geophys. J. R. astr. Soc.", 33, pp. 389-404. 
Knopoff, L., Г. Schwab, K. Nakanishi, and F. Chang, 1974. - Evaluation of $\mathrm{Lg}$ as a discriminant among different continental crustal structures. "Geophys. J. R. astr. Soc. ", 39, pp. 41-70.

Kovach, R., and D. Anderson, 1964. - Higher mode surface waves and their bearing on the structure of the earth's mantle. "Bull. Seism. Soc. Am.", 54. pp. 161-182.

Larue, B., J. Daniel, C. Jounnnic. and J. Recy, 1977. - The south Renuel trough: Evidence for a Jossil spreading zone. in "Geodynamics in South-West Pacific, Editions Technip. Paris, pp. 51-61.

Luyendyk, B., K. MAC Donald, and W. Bryan, 1973. - Rifting history of the Woodlark basin in the southwest Pacific. "Geol. Soc. Am. Bull.", 84. pp. $1125-1134$.

MACKENZIE, D.. 1976. - Nature and origin of late Cainozoic volcanoes in western Papua New Guinea. in "Volcanism in Australasia ", R. Johnson (editor), Elsevier Co., pp. 221-238.

Milsom, J., 1970. - Woodlark basin, a minor center of sea-floor spreading in Melanesia. «J. Geophys. Res.», 75, pp. 7335-7339.

Milsom, J., 1973. - Papuan ultramafic belt: gravity anomalies and the emplacement of ophiolites. "Geol. Soc. Am. Bull. ", 84, pp. 2243-2258.

Molnar, P., and J. Oliver, 1969. - Lateral variations of attenuation in the upper mantle and discontinuities in the lithosphere. "J. Geophys. Res.", 74, pp. 2648-2682.

Oliver, J., M. Ewing, and F. Press, 1955. - Crustal structure of the Arctic regions from the Lg phase. "Geol. Soc. Am. Bull.", 66, pp. 1063-1074.

Oliver, J., Ewing, M., 1975. - Higher modes of continental Rayleigh waves, "Bull. Seism. Soc. Am. ", 47, 187-204.

Oljver, J., Ewing, M., 1958 a. - Normal modes of continental surface waves. "Bull. Seism. Soc. Am. ", 48, 33-49.

Oliver, J., EnING, M., $1958 \mathrm{~b}$. - The effect of surficial sedimentary layers on continental surface waves, "Bull. Seism. Soc. Am.», 48, 339-354.

Oliver, J., IsAcKs, B., 1867. - Deep earthquake zones, anomalous siructures in the upper mantle, and the lithosphere, "J. Geophys. Res.", 72, pp. 4259-4275.

Press, F., Ewing, M., Two slow surlace waves across North America, "Bull. Seism. Soc. Am. ", 42, 219-228.

Ruzaikin, A., I. Nersesov, V. Khalturin, Molnar, P., 1977. - Propagation of Lg and lateral variations in crustal structure in Asia, «J. Geophys. Res.", 82. pp. 307-316.

Schuberr, G., C. Froldevaux, Yuen D., 1976. - Oceanic lithosphere and asthenosphere: Thermal and mechanical structure, "J. Geophys. Res.", 81, pp. 3525-3540. 
Shuriset, D., 1962. - The high frequency $P$ and $S$ phases from the West Indies, "Bull. Seism. Soc. Am.», 52, pp. 957-962.

SHURBET, D., 1964. - The high frequency $S$ phase and the structure of the upper mantle. « J. Geophys. Res.", 69, pp. 2065-2070.

Stephens, C., IsACKS, B., 1977. - Toward an understanding of Sn: normal modes of Love waves in an oceanic structure. «Bull. Seism. Soc. Am.», 67, pp. 69-78.

Sutton, G., WAiker, D., 1972. - Oceanic mantle phases recorded on seismographs in the northwestern Pacific at distances between $7^{\circ}$ and $40^{\circ}$. "Bull. Seism. Soc. Am.», 62, pp. 631-655.

Turcotte, D., Oxburgh, E., 1978. - Mechanisms of continental drift. " Reports on Progress in Physics », 41, pp. 1249-1312.

UTsU, T., 1971. - Seismological evidence for anomalous structure of island arcs with special reference to the Japanese region, "Rev. Geophys Space Phys. », 9. pp. 839-890.

WALKer, D., 1977. - High-frequency $P_{n}$ and $S n$ phases recorded in the western Pacific. J. Geophys. Res., 82, pp. 3350-3360.

Yoshu, T., Y. Kono, Iто, K., 1976. - Thickening of the oceanic lithosphere, in The Geophysics of the Pacific Ocean Basin and Its Margin. G. Sutton, M. Manghnani, and R. Moberly (editors). Geophysical Monograph 19. American Geophysical Union, Washington, D. C. 423-430. 